\title{
What is the economic impact of preschool viral upper respiratory infection?
}

\section{To the Editor:}

In a previous issue of the European Respiratory Journal STEVENS et al. [1] suggested that preschool children with wheeze account for a significant proportion of the UK healthcare budget. Most preschool wheezing is caused by viral infection and, therefore, we wondered how much preschool children with upper respiratory tract infection (URTI) without wheeze would cost the National Health Service?

On average, a preschool child will catch 6-8 URTIs per year [2], and $11 \%$ of children $<14$ yrs will be taken to their family doctor when unwell. These figures may be higher in younger children [3]. If a child has six colds per year and is seen by a doctor for $11 \%$ of these infections, then, based on the 2.94 million UK preschool population estimate and a $£ 16$ consultation cost estimation [1], the primary care costs of viral URTI would be $£ 31$ million. This compares to the $£ 34$ million estimated by STEVENS et al. [1] as the cost of preschool wheezing. Therefore, the additional cost burden of wheeze seems small.
We believe the villains are not wheeze and asthma but the respiratory viruses!

\section{D.S. Urquhart, S.A. McKenzie}

Paediatric Respiratory Medicine, Queen Elizabeth Children's Services, Royal London Hospital, London, UK.

\section{References}

1. Stevens CA, Turner D, Kuehni CE, Couriel JM, Silverman $\mathrm{M}$. The economic impact of preschool asthma and wheeze. Eur Respir J 2003; 21: 1000-1006.

2. Coughs and colds in children. www.prodigy.nhs.uk/ clinicalguidance/releasedguidance/webBrowser/pils/PL43.htm

3. Bruijnzeels MA, Foets M, van der Wouden JC, van der Heuvel WJ, Prins A. Everyday symptoms in childhood: occurrence and general practitioner consultation rates. Br J Gen Pract 1998; 48: 880-884.

\section{Exhaled breath condensate pH}

\section{To the Editor:}

VAUGHAN et al. [1] are to be congratulated for the most extensive study of the $\mathrm{pH}$ of exhaled breath condensates (EBC) yet reported. However, there is reason to doubt that the $\mathrm{pH}$ of the condensate provides a reliable measure of the $\mathrm{pH}$ of fluid lining the airways. As noted in our recent study [2], the average concentration of $\mathrm{NH}_{4}{ }^{+}$is 20 times greater than that of any other EBC cation in normal condensates, and $\mathrm{NH}_{4}{ }^{+}$accounts for most of the ions and buffer in the condensate (as judged by total conductivity).

Several previous studies have shown that most of this $\mathrm{NH}_{4}{ }^{+}$ is derived from $\mathrm{NH}_{3}$ generated in the mouth, in part from the bacterial degradation of urea [2-4]. In the study by VAUGHAN et al. [1], collection of condensates through endotracheal tubes did not seem to have an effect upon average $\mathrm{pH}$. Since both intubation and tracheostomy significantly reduce $\mathrm{NH}_{4}{ }^{+}$ concentrations of the EBC [2, 4], they should be associated with more acidic condensates. This paradox could only be explained if intubation also reduced concentrations of some atmospheric or oral acid (e.g. residual $\mathrm{CO}_{2}$ or acetic acid) in the EBC. It must be concluded that the $\mathrm{pH}$ of normal condensates reflects buffering by these volatile constituents from the mouth, rather than buffers in the airway fluid, and therefore $\mathrm{EBC} \mathrm{pH}$ cannot provide reliable estimates of airway $\mathrm{pH}$.

Although the normal condensate $\mathrm{pH}$ is set by oral and atmospheric buffers, HUNT and coworkers [5, 6] observed "acidopnoea" in asthmatics, which they attributed to airway acidification. We have suggested that reductions in exchange of $\mathrm{NH}_{3}$ in the mouth and condenser are responsible in part for the reduction in $\mathrm{EBC} \mathrm{NH}_{4}^{+}$seen in asthmatics [7], and consequently contribute to acidification. It is also possible that reflux of gastric fluid, which is extraordinarily common in asthmatics [8], is responsible for EBC acidification. Aerosolisation of tiny quantities of gastric acid $(\mathrm{pH}$ often $1-2)$ from the stomach or pharynx would be difficult to avoid or detect in these patients but could have a profound effect on $\mathrm{EBC} \mathrm{pH}$.

\section{R.M. Effros}

Harbor-UCLA Medical Center, Torrance, CA, USA.

\section{References}

1. Vaughan J, Ngamtrakulpanit L, Pajewski TN, et al. Exhaled breath condensate $\mathrm{pH}$ is a robust and reproducible assay of airway acidity. Eur Respir J 2003; 22: 889-894.

2. Effros RM, Biller J, Foss B, et al. A simple method for estimating respiratory solute dilution in exhaled breath condensates. Am J Respir Crit Care Med 2003; 168: $1500-1505$.

3. Norwood DM, Wainman T, Lioy PJ, Waldman JM. Breath 